\title{
SEROLOGIC SCREENING AND GENETIC TESTING AMONG BRAZILIAN PATIENTS WITH CELIAC DISEASE AND THEIR FIRST DEGREE RELATIVES
}

\author{
Rita de Cássia Azevedo MARTINS ${ }^{1}$, Lenora GANDOLFI'1, 2, ${ }^{3}$, Inês Cristina MODELLI ${ }^{1,3}$, \\ Rodrigo Coutinho de ALMEIDA', ${ }^{1,}$ Luiz Claudio CASTRO ${ }^{3}$ and Riccardo PRATESI, 2,3
}

\begin{abstract}
Context - Celiac disease susceptibility has been shown to be associated with the HLA alleles DQA $1 * 0501$ and DQB $1 * 0201$ (together encoding the DQ2 heterodimer) that are present in practically all celiac disease patients. The DQ8 heterodimer (coded by DQA1*03-DQB1*0302), which is carried on a DRB1*04 (DR4) haplotype, is commonly encoded for by the few celiacs who do not carry the DQ2 heterodimer. Only a few celiac disease patients have been reported without these known risk alleles. Objective - To assess the prevalence of celiac disease in a group of first degree relatives of celiac patients, and the frequency of HLA predisposing alleles both in the group of celiac patients and in their first degree relatives, identifying those first degree relatives who would need further screening for celiac disease. Methods - Ninety celiac disease patients and 207 first degree relatives underwent serologic screening for celiac disease (endomysial and transglutaminase antibodies) followed by intestinal biopsy in positive patients. The HLA-DQA 1 *0501, DQB $1 * 0201$ and DRB1*04 frequencies of celiac patients and their first degree relatives were determined utilizing the PCR method. Results - All the celiac disease patients $(\mathrm{n}=90)$ with the exception of one $(1.1 \%)$ carried at least one of the alleles investigated. Altogether $11(5.3 \%)$ of the investigated first degree relatives did not carry any of the alleles studied. Fourteen (6.7\%) new cases of celiac disease were found among the 207 celiac disease patients first degree relatives. Conclusions - Considering the cost-benefit of the HLA typing of all the first degree relatives of celiac patients, their HLA status should be decided on an individual basis, taking account of their profile and preferences, and the existence of other medical conditions.
\end{abstract}

HEADINGS - Celiac disease. Serological tests. HLA antigens. Alleles. Genetic predisposition to disease. Family.

\section{INTRODUCTION}

Celiac disease $(\mathrm{CD})$ is an autoimmune disorder triggered by the ingestion of gluten and related cereals, resulting in jejunal villous atrophy and flattening of mucosa. The disease has a strongly genetic basis that has been confirmed by a concordance rate among monozygotic twins and a higher prevalence among family members of celiac patients ${ }^{(48)}$.

$\mathrm{CD}$ was initially considered a rare malabsorption syndrome in childhood affecting predominantly Europeans or individuals of European ancestry. Today CD is recognized as a common disorder with an increasing prevalence in the general population, being described in several different non-European countries ${ }^{(11)}$. It manifests at any age, with a large proportion of new cases being diagnosed in patients with extraintestinal manifestations. Prevalence in Brazil is apparently similar to those found in European countries. Screening studies performed during the last decade showed a prevalence varying from 1:213 to $1: 681$ in presumably healthy blood donors ${ }^{(19,31,34)}$ and from 1:53 to $1: 417$ in the general population in different Brazilian regions ${ }^{(15,35,38,44)}$.

Although $\mathrm{CD}$ is one of the most common autoimmune lifelong diseases, most affected individuals remain undiagnosed ${ }^{(12)}$. This is probably due to the fact that many patients have atypical symptoms or none at all. CD aggregates in families and this is the first observable clue to its genetic susceptibility. Concordance in monozygotic twins is high at approximately $75 \% 0^{(21)}$, whereas prevalence among first-degree relatives (FDR) varies from $5 \%$ to $22.5 \%{ }^{(16)}$.

$\mathrm{CD}$ has a strong genetic association with the human leucocyte antigen (HLA) that is estimated to account for up to $40 \%$ of genetic load ${ }^{(4)}$. Practically all patients with CD are positive for the DQA $1 * 0501$ and DQB1 $* 2$ alleles which, either in cis or in trans, form the DQ2 heterodimer ${ }^{(43)}$. Most CD patients who lack the entire DQ2 complex have at least one of the alleles coding for it,

University of Brasília School of Health Sciences, Brasilia, DF; ${ }^{2}$ Celiac Disease Investigation Center, University of Brasilia; ${ }^{3}$ Pediatric Department, Brasília University Hospital, University of Brasilia, Brasilia DF, Brazil

Correspondence: Dr. Riccardo Pratesi - SQN 212 - Bloco F - apt. 605 - 70864-060 - Brasília, DF, Brazil. E-mail: pratesir@unb.br or pratesir@gmail.com 
either DQA1*0501 or DQB1*02. The DQ8 heterodimer (coded by $\mathrm{DQA} 1 * 03-\mathrm{DQB} 1 * 0302)$, which is carried on a DRB1*04 (DR4) haplotype, is commonly encoded for by the few celiacs who do not carry the DQ2 heterodimer. Only a few CD patients have been reported without these known risk alleles ${ }^{(25,37)}$.

Considering that as many as $20 \%-30 \%$ of healthy subjects in the general population are also carriers of these alleles, the value of HLA typing in CD is mainly considered for its negative predictive value since the disorder very rarely develops unless a person carries alleles that encode for HLA-DQ2 or DQ8 ${ }^{(22,25)}$. Despite the fact that its results are not absolutely certain, HLA typing for CD is generally considered as an important tool in the definition of dubious cases and in the screening strategy for asymptomatic individuals who belong to at-risk groups such as the case of FDR of celiac patients. The HLA alleles are lifelong stable markers and their typing may detect genetically susceptible or non-susceptible subjects long before the possible appearance of the disorder ${ }^{(23,30)}$.

Studies on the prevalence of HLA alleles predisposing to $\mathrm{CD}$ in the general population and studies on the risk among FDR of celiac patients remain scarce in Brazil. In view of the largely mixed racial background of the Brazilian population, it is likely that such studies will show significant regional variations. Consequently, the aims of the present study were to assess: 1 . the frequency of undiagnosed CD among FDR of celiac patients applying highly sensitive serologic tests (IgA-EMA and IgA-tTG), and 2. the frequency of HLA predisposing alleles DQA1*0501 and DQB1*0201 and DRB1*04 in a group of CD patients, and their FDR.

\section{METHODS}

\section{Population and design}

Between January 2004 and December 2008, FDR (parents, siblings and offspring) of $90 \mathrm{CD}$ patients diagnosed according to the European Society for Paediatric Gastroenterology, Hepatology and Nutrition (ESPGHAN) criteria ${ }^{(39)}$ who attended the Brasilia University Hospital Gastroenterology Clinics, Brasília, DF, Brazil, were invited to take part in the study. None of these index cases were related to each other. The group was composed of $55(61.1 \%)$ females and $35(38.9 \%)$ males (mean age at diagnosis, 15.5 years; age range, 1 to 55 years).

Of the initial group of 298 identified FDR, 91 could not be located or refused to participate. The remaining group of 207 family members included 122 parents (44 fathers and 78 mothers, aged $18-75$ years; mean age 40 years; median 42 years), 63 siblings ( 29 brothers and 34 sisters, aged $1-48$ years; mean age 16 years; median 14 years) and 22 offspring (11 males and 11 females, aged 1-32 years; mean age 10 years; median 11 years).

The Brasilia University Hospital is a general hospital attending to mainly low-income population originating from the outskirts and suburban regions of the city of Brasilia (Federal District). Racially, this is a predominantly mixed-blood population in which a considerable contribution of European ancestry can be detected in association with a variable parcel of other races, mainly Africans and, to a lesser extent, Amerindians.
The study protocol was approved by the institution Ethics Committee of the Brasilia University School of Health Sciences (protocol CEP-FM 051/2003). Eligible patients and healthy family members received written and oral information concerning the use of their blood in this study, and all provided signed consent. All participant family members were on a gluten-containing diet when the serologic tests were performed. On each participant relative was applied a standardized questionnaire focusing on the presence of gastrointestinal signs and symptoms, and the presence of other symptoms, not related to the gastrointestinal tract but frequently seen in association with CD (atypical form).

\section{Serologic markers}

Blood samples were centrifuged to separate the serum and stored at $-20^{\circ} \mathrm{C}$ for further use. All sera were previously tested by turbidimetric immunoquantification (COBAS MIRA, Roche Diagnostic Systems) to determine immunoglobulin A level, to exclude IgA deficiency. The serologic screening included: (1) Serum IgA endomysial antibody test (IgA-EMA) determined by indirect immunofluorescence method using sections from the distal portion of monkey's esophagus (The Binding Site, Birmingham, UK) as substrate. The patient's serum was diluted 1:5 in phosphate buffer at $\mathrm{pH}$ 7.4. The final reaction was detected with fluorescein isothiocyanate rabbit anti-human IgA conjugate (Biosystems, Barcelona, Spain). Two independent observers examined all the slides and results were considered positive when bright green fluorescence of the reticulin like staining of smooth muscle was seen under fluorescence microscope; (2) IgA human reconbinant antitransglutaminase antibody (IgA-tTG) evaluated with by ELISA, according to manufacturer instructions (INOVA Diagnostic Inc., San Diego, California, USA).

\section{Genetic markers}

Genomic DNA was extracted from peripheral venous blood using a commercial kit (Illustra ${ }^{\mathrm{TM}}$ Blood genomicPrep Mini Spin, GE Helathcare, Buckinghamshire, UK). Celiac patients and relatives were typed for the presence of HLA DQ2 (DQA1*0501,DQB1*0201) and DRB1*04 by PCR applying the method described by Sacchetti et al. ${ }^{(41)}$. PCR products were separated by pre-stained ethidium bromide agarose gel electrophoresis and subsequently visualized by UV illumination as separated bands of $177 \mathrm{bp}(\mathrm{DRB} 1 * 04)$, $144 \mathrm{bp}(\mathrm{DQA} 1 * 05)$ and $110 \mathrm{bp}(\mathrm{DQB} 1 * 0201)$. Equivocal results were retested and confirmed using the kit Eu-DQ (Eurospital, Trieste, Italy).

\section{Small bowel histology}

Intestinal biopsy was suggested to all IgA-EMA or IgAtTG positive subjects. In addition, serologic follow-up was advised to all relatives who were carriers of the predisposing HLA alleles. Children underwent small intestinal biopsy with a Watson pediatric capsule, samples being taken at the ligament of Treitz. In adults, biopsy samples were obtained through an endoscopy procedure, using an Olympus gastroscope (Tokyo, Japan) with four to five fragments being taken from 
the second portion of the duodenum. All biopsy specimens were blindly evaluated by a pathologist and a gastroenterologist and classified according to $\mathrm{Marsh}^{(29)}$ as type normal (O), infiltrative (I), infiltrative hyperplastic (II), flat destructive (III), and atrophic hypoplastic (IV).

\section{RESULTS}

Increased levels of IgA-tTG were present in 18 of the 207 CD relatives (8.7\%), whereas 14 of $207(6.7 \%)$ were both IgAtTG and IgA-EMA positive. Three of the four subjects who were $\mathrm{tTG}$ positive and EMA negative, respectively aged 6, 13, 34 years, were carriers of the DQ2 heterodimer and underwent jejunal biopsy with normal results. The fourth subject, an asymptomatic mother aged 48 years, that had disclosed only a slightly increased level of IgA-tTG was negative for predisposing alleles and was consequently considered as non-celiac. Intestinal biopsy was suggested and subsequently carried out in all the 14 subjects positive in both serological tests, and reported compatible with the diagnosis of $\mathrm{CD}$ in all cases.

Eleven $(78.5 \%)$ of these 14 patients were carriers of the HLA-DQ2 heterodimer, 2 carried concomitantly the DQ2 heterodimer and the DRB $1 * 04$ allele. Only 1 of the CD diagnosed relatives was negative for the $\mathrm{DQ} 2$ heterodimer, being a carrier of a single DQB $1 * 0201$ allele in association with the DRB $1 * 04$ allele. Consequently, the strict prevalence of biopsy proven celiac disease among the 1st degree relatives of CD patients was 6.7\% (14/207). Among this group of 14 relatives diagnosed as celiac, $6(4.9 \%)$ were parents (2 mothers, 4 fathers), $6(9.5 \%)$ were siblings ( 5 sisters, 1 brother) and 2 $(9 \%)$ were offsprings (1 girl, 1 boy) (Table 1$)$.

Only one relative showed a silent form of the disease, despite the fact that she was positive in both serologic tests, was a carrier of a DQ2 allele, and her biopsy sample disclosed Marsh III jejunal lesions. The remaining 13 disclosed a variety of signs and symptoms, including diarrhea, anemia, abdominal distension, fatigue, recurrent abdominal pain, joint pain and depression.

Among the 90 index cases, the DQ2 heterodimer was present alone in $60(66.6 \%)$, and in $18(20 \%)$ it was detected in association with the DRB $1 * 04$ allele. Amid the remaining celiac patients, $2(2.2 \%)$ carried only the DRB $1 * 04$ allele while in $5(5.5 \%)$ this allele was detected in association with one of the two alleles (DQA $1 * 0501$ or DQB1*0201) that compose the DQ2 heterodimer. Furthermore, in 2 patients $(2.2 \%)$, a single DQA $1 * 0501$ was present and in another $2(2.2 \%)$, a single DQB1*0201 was found. In $1(1.1 \%)$ celiac patient, none of the predisposing HLA alleles was detected.

Table 2 shows the results of the HLA typing of 90 celiac disease patients, their 14 celiac positive relatives and 193 nonceliac relatives on the basis of disease status and kinship degree.

TABLE 1. Serologic, molecular, histologic and clinical findings in 14 first-degree relatives identified as celiac

\begin{tabular}{|c|c|c|c|c|c|c|c|}
\hline $\mathbf{N}$ & Age & Gender & Kinship & tTG & EMA & HLA & Biopsy \\
\hline 1 & 8 & female & daughter & 184,8 & Positive & DQB1\& DRB1 & Marsh III \\
\hline 2 & 28 & female & mother & 91,7 & Positive & DQ2 & Marsh III \\
\hline 3 & 5 & male & brother & 246,5 & Positive & DQ2 & Marsh III \\
\hline 4 & 40 & female & sister & 94,2 & Positive & DQ2 \& DRB1 & Marsh III \\
\hline 5 & 12 & female & sister & 82,8 & Positive & DQ2 & Marsh I \\
\hline 6 & 22 & female & sister & 213,2 & Positive & DQ2 & Marsh III \\
\hline 7 & 59 & male & father & 109,3 & Positive & DQ2 & Marsh II \\
\hline 8 & 36 & female & mother & 37,4 & Positive & DQ2 & Marsh I \\
\hline 9 & 35 & male & father & 31.3 & Positive & DQ2 & Marsh III \\
\hline 10 & 54 & male & father & 71,85 & Positive & DQ2 & Marsh I \\
\hline 11 & 2 & male & Son & 92,54 & Positive & DQ2 & Marsh III \\
\hline 12 & 75 & male & father & 43.4 & Positive & DQ2 \& DRB1 & Marsh II \\
\hline 13 & 45 & female & sister & 63,61 & Positive & DQ2 & Marsh III \\
\hline 14 & 19 & female & sister & 85,6 & Positive & DQ2 & Marsh III \\
\hline
\end{tabular}

DQ2 = DQA1*0501, DQB1*0201; DRB1 =DRB1*04; DQA1 = DQA1*0501; DQB1 = DQB1*0201

TABLE 2. HLA status of the probands $(\mathrm{n}=90)$ and their first-degree relatives $(\mathrm{n}=207)$

\begin{tabular}{|c|c|c|c|c|c|c|c|c|c|}
\hline & \multirow[b]{2}{*}{ Probands } & \multicolumn{3}{|c|}{ Celiac relatives } & \multicolumn{5}{|c|}{ Non-celiac relatives } \\
\hline & & Parents & Siblings & Offspring & Celiac FDR & Parents & Siblings & Offspring & Non-celiac FDR \\
\hline DQ2 & 60 & 5 & 5 & 1 & 11 & 47 & 25 & 9 & 81 \\
\hline DRB1 & 2 & 0 & 0 & 0 & 0 & 5 & 4 & 0 & 9 \\
\hline DQ2 \& DRB1 & 18 & 1 & 1 & 0 & 2 & 17 & 5 & 3 & 25 \\
\hline DQA1 \& DRB1 & 1 & 0 & 0 & 0 & 0 & 3 & 3 & 1 & 7 \\
\hline DQB1 and DRB1 & 4 & 0 & 0 & 1 & 1 & 9 & 0 & 1 & 10 \\
\hline Only DQA1 & 2 & 0 & 0 & 0 & 0 & 14 & 7 & 0 & 21 \\
\hline Only DQB1 & 2 & 0 & 0 & 0 & 0 & 15 & 9 & 5 & 29 \\
\hline Absence of DQ2/DRB1 & 1 & 0 & 0 & 0 & 0 & 6 & 4 & 1 & 11 \\
\hline Total & 90 & 6 & 6 & 2 & 14 & 116 & 57 & 20 & 193 \\
\hline
\end{tabular}

DQ2 = DQA $1 * 0501, \mathrm{DQB} 1 * 0201 ; \mathrm{DRB} 1=\mathrm{DRB} 1 * 04 ; \mathrm{DQA} 1=\mathrm{DQA} 1 * 0501 ; \mathrm{DQB} 1=\mathrm{DQB} 1 * 0201$ 
Among the 193 non-celiac FDR, the heterodimer DQ2 was found in $81(42 \%)$, and in $25(13 \%)$, was concomitantly seen associated with the allele DRB1*04. DRB $1 * 04$ was present alone in $9(4.6 \%)$, associated with DQA1 in $7(3.6 \%)$, and with DQB1 in $10(5.2 \%)$. Isolated DQA1 and DQB1 were respectively observed in $21(10.9 \%)$ and $29(15 \%)$ subjects. The absence of any $\mathrm{CD}$ predisposing alleles was ascertained in $11(5.7 \%)$ subjects.

\section{DISCUSSION}

Although previous studies have focused on the prevalence of celiac disease among first-degree relatives of celiac patients $^{(1,28,46)}$, surveys of prevalence of CD predisposing HLA alleles in the general population and particularly in FDR of patients with CD are extremely rare in Brazil. Silva et al. ${ }^{(42)}$, in a first report on the association of HLA and CD in Brazilian population, concluded that susceptibility alleles observed in Brazilian patients were similar to those observed in European studies. However, most of the patients studied by these authors were of Italian ancestry; it is likely that due to the remarkably mixed racial background of the Brazilian population, the $\mathrm{CD}$ predisposing allele frequency in Brazil will show significant regional variations.

In this study, we defined an individual as celiac when found to be serologically positive and when the individual's biopsy result is consistent with $\mathrm{CD}$. Although we recommend and obtained small bowel biopsy from all subjects disclosing predisposing alleles and positivity for one or both serologic tests, $\mathrm{CD}$ was not confirmed in four exclusively tTG positive patients. Our clinical experience with our serologic assays agrees with that of the literature whereby the IgAanti-tTG is more sensitive and the IgA-EMA is more $\operatorname{specific}^{(3,8,10)}$. False positive EMA results are rare and IgA-EMA testing is nearly $100 \%$ specific $^{(45,47)}$. False negative results can be obtained in older age groups ( $>35$ years) and in children younger than 2 years $^{(6,9)}$.

In our series, the prevalence of $\mathrm{CD}$ among relatives was 14/207 (6.7\%) and the CD predisposing alleles, DQ2 (DQA1*0501 and DQB1*02) and/or DRB1/DQ8, alone or in association were present in all newly diagnosed celiac relatives. In contrast among the non-celiac relatives, at least one of the risk alleles was found in $182(94.3 \%)$ and the heterodimer DQ2 was found alone or in association with the DRB $1 * 04$ allele in $106(54.9 \%)$.

It has been demonstrated that practically all $\mathrm{CD}$ patients carry HLA-DQ2 and/or HLA-DQ8 molecules or one chain of the DQ2 heterodimer, coded by DQA $1 * 05$ ( $\alpha 5$ chain) or DQB1 *02 ( $\beta 2$ chain) alleles, and that $\mathrm{CD}$ only exceptionally occurs in the absence of at-risk DQ factors ${ }^{(25)}$. A variable risk gradient does exist, depending on which susceptible DQ alleles are present, ranging from 1:7 in subjects carrying both alleles DQ2 and DQ8 to 1:2518 in individuals who do not display any predisposing allele ${ }^{(30)}$. A significant increased risk of developing $\mathrm{CD}$ is also determined by the presence of one (risk of 1:35) or two copies (risk of $1: 10$ ) of the allele DQB $1 * 02$. The homozigosis of this allele is associated with an earlier onset, increased anti
tTG antibody levels, presence of complications and increased severity of the disease. On the other hand, the presence of DQA $1 * 05$ allele alone is associated with extremely low odds of developing gluten intolerance (risk of 1:1842)(2,26,30).

The prevalence of $6.7 \%$ found in the present study is in agreement with the findings of several previous studies in which the prevalence of $\mathrm{CD}$ among FDR varied between $4.5 \%$ and $9.5 \% 0^{(7,17,18,24)}$. In a more recent study of 158 adult FDR, Biagi et al. ${ }^{(5)}$ found a prevalence of $17.7 \%$, confirming that $\mathrm{CD}$ relatives are at high risk of developing gluten intolerance, reinforcing the need for extensive screening policy in these subjects. Genetic testing before serologic screening has been proposed to reduce the number diagnostic testing of relatives that, being negative for HLA-DQ2 or DQ8, have a minimum risk of developing CD. In this way, between $10 \%$ to $20 \%$ FDR could be excluded from serologic testing ${ }^{(26)}$. However, in a recent study, Chang and Green $^{(13)}$ concluded that the use of HLA typing before serologic screening for $\mathrm{CD}$, at the current cost of serologic assays, would not reduce screening expenses. A substantial reduction in the cost of HLA typing would be required before it could become an affordable option. In situations in which a high-throughput approach is needed, HLA-tagging single-nucleotide polymorphisms (SNPs), which has shown high specificity and sensitivity in the identification of celiac-disease-associated HLA risk haplotypes, could be used with significant cost and time savings ${ }^{(27,32)}$.

On the other hand, HLA typing of serologically negative relative would be justifiable to determine their future risk of developing CD. The fact that HLA positive subjects can become celiac at any time during their lifetime ${ }^{(7,33,36)}$ would imply the need to periodically test those relatives who have tested negative for celiac antibodies the first time. HLA typing would preclude further work-up of these individuals and eliminate the need of future surveillance clinic visits ${ }^{(40)}$.

Nevertheless, the appropriateness and timing of further screening of asymptomatic HLA positive FDR of celiac patients is still an open question. Several follow-up studies advocate the periodic reevaluation of relatives who have been negative on initial screening ( $^{(7,20,24,33,36)}$ but a close analysis of these studies show that the number of subjects was low, the study designs were different, and the incidence figures were not necessarily comparable. However, it can be seen that within a follow-up from 7 to 12 years, about $2 \%$ to $5 \%$ of seronegative relatives developed the disease ${ }^{(14)}$. Biagi et al. ${ }^{(5)}$, in a 7 -year follow-up study of 158 adult FDR, concluded that the annual incidence of CD in his study group was $0.4 \%$. They did not perform genetic studies due to high cost considerations and also cited that almost $50 \%$ of the serologically negative FDR refused a second test. These authors concluded that, in view of the low incidence rate, further studies are necessary before deciding whether adult FDR should be followed up over time and which is the best screening strategy in terms of the costbenefit relationship. They stressed that their data are valid for adult FDR but not for children. Similar studies are necessary among children in whom the greater life expectancy makes the need for follow-up more important.

In conclusion, we found $14(6.7 \%)$ new cases of DC among 207 FDR of 90 biopsy-proven celiac patients. The prevalence 
of DC and the frequency of predisposing HLA alleles in this FDR group are similar to those previously described in other studies. HLA typing excluded $11(5.7 \%)$ FDR from further follow-up and identified other $21(10.9 \%)$ with a low grade risk of developing CD in the future (carriers of a single DQA1 allele).

In line with Chang et al. ${ }^{(13)}$ we did not find HLA typing to be cost-effective, considering that it is a time consuming process and that it would be beneficial solely to a relatively small percentage of FDR. In our opinion, considering the high negative predictive value of the absence of the HLA DQ2 and DQ8 predisposing alleles, its determination would be only justified in those cases in which the definitive diagnosis of $\mathrm{CD}$ is questionable, allowing the exclusion of negative HLA patients from further serologic testing.

Martins RCA, Gandolfi L, Modelli IC, Almeida RC, Castro LC, Pratesi R. Rastreamento sorológico e tipagem genética em pacientes com doença celíaca e em seus parentes de primeiro grau. Arq Gastroenterol. 2010;47(3):257-62.

RESUMO - Contexto - A susceptibilidade para a doença celíaca está principalmente associada à presença dos alelos HLA DQA $1 * 0501$ e DQB $1 * 0201$ (que conjuntamente codificam o heterodímero DQ2), os quais são praticamente encontrados em todos os pacientes celíacos. O heterodímero DQ8 (codificado pelos alelos DQA1*03 e DQB1*0302) associado ao haplotipo DRB1*04 (DR4) é comumente encontrado nos pouco pacientes celíacos que não carregam o heterodímero DQ2. Objetivos - Determinar a prevalência de doença celíaca em grupo de parentes de primeiro grau de pacientes celíacos e a frequência da presença de alelos HLA predisponentes tanto nos pacientes celíacos como em seus parentes de primeiro grau, identificando neste último grupo, os que iriam necessitar de futuros testes diagnósticos. Métodos - Noventa pacientes celíacos e 207 dos seus parentes de primeiro grau foram submetidos a testes sorológicos para a doença celíaca (pesquisa de anticorpos antiendomísio e antitransglutaminase) sendo a seguir efetuada biopsia intestinal nos pacientes sorologicamente positivos. Tanto nos pacientes celíacos como em seus parentes foi determinada a frequência de alelos HLA-DQA1*0501, DQB1*0201 e DRB1*04 pela técnica de PCR. Resultados - Todos os pacientes celíacos (n = 90), com exceção de um (1.1\%) eram portadores de pelo menos um dos alelos investigados. Onze (5.3\%) dentre os 207 parentes de celíacos não carregavam nenhum dos alelos predisponentes para DC. Quatorze (6.7\%) novos casos de doença celíaca foram identificados entre os 207 parentes investigados. Conclusões - Considerando o fator custo-benefício da tipagem rotineira dos alelos HLA predisponentes em todos os parentes de primeiro grau de pacientes celíacos, é opinião dos autores que a identificação do perfil HLA deverá ser decidida em bases individuais, levando-se em conta as características de cada indivíduo, suas preferências e a concomitante existência de outras patologias médicas.

DESCRITORES - Doença celíaca. Testes sorológicos. Antígenos HLA. Alelos. Predisposição genética para doença. Família.

\section{REFERENCES}

1. Almeida PL, Gandolfi L, Modelli IC, Martins RC, Almeida RC, Pratesi R. Prevalence of celiac disease among first degree relatives of Brazilian celiac patients. Arq Gastroenterol. 2008;45:69-72.

2. Al-Toma A, Goerres MS, Meijer JW, Peña AS, Crusius JB, Mulder CJ. Human leukocyte antigen-DQ2 homozygosity and the development of refractory celiac disease and enteropathy-associated T-cell lymphoma. Clin Gastroenterol Hepatol. 2006;4:315-9.

3. Baudon JJ, Johanet C, Absalon YB, Morgant G, Cabrol S, Mougenot JF Diagnosing celiac disease: a comparison of human tissue transglutaminase antibodies with antigliadin and antiendomysium antibodies. Arch Pediatr Adolesc Med. 2004;158:584-8.

4. Bevan S, Popat S, Braegger CP, Busch A, O’Donoghue D, Falth-Magnusson K, Ferguson A, Godkin A, Hogberg L, Holmes G, Hosie KB, Howdle PD, Jenkins H, Jewell D, Johnston S, Kennedy NP, Kerr G, Kumar P, Logan RF, Love AH, Marsh M, Mulder CJ, Sjoberg K, Stenhammer L, Walker-Smith J, Marossy AM, Houlston RS. Contribution of the MHC region to the familial risk of coeliac disease. J Med Genet. 1999;36:687-90.

5. Biagi F, Campanella J, Bianchi PI, Zanellati G, Capriglione I, Klersy C, Corazza GR. The incidence of coelic disease in adult first degree relatives. Dig Liver Dis. 2008;40:97-100.

6. Boger CP, Thomas PW, Nicholas DS, Surgenor SL, Snook JA. Determinants of endomysial antibody status in untreated coeliac disease. Eur J Gastroenterol Hepatol. 2007:19:890-5.

7. Bonamico M, Ferri M, Mariani P, Nenna R, Thanasi E, Luparia RP, Picarelli A, Magliocca FM, Mora B, Bardella MT, Verrienti A, Fiore B, Uccini S, Megiorni F, Mazzilli MC, Tiberti C. Serologic and genetic markers of celiac disease: a sequential study in the screening of first degree relatives. J Pediatr Gastroenterol Nutr. 2006;42:150-4.

8. Brandt KG, Silva GA. Seroprevalence of celiac disease at a general pediatric outpatient clinic. Arq Gastroenterol. 2008;45:239-42.
9. Bürgin-Wolff A, Gaze H, Hadziselimovic F, Huber H, Lentze MJ, Nusslé D, Reymond-Berthet C. Antigliadin and antiendomysium antibody determination for coeliac disease. Arch Dis Child. 1991;66:941-7.

10. Carroccio A, Vitale G, Di Prima L, Chifari N, Napoli S, La Russa C, Gulotta G, Averna MR, Montalto G, Mansueto S, Notarbartolo A. Comparison of anti-transglutaminase ELISAs and an anti-endomysial antibody assay in the diagnosis of celiac disease: a prospective study. Clin Chem. 2002;48:1546-50.

11. Catassi C, Cobellis, G. Coeliac disease epidemiology is alive and kicking, especially in the developing world. Dig Liver Dis. 2007;39:908-10.

12. Catassi C, Kryszak D, Louis-Jacques O, Duerksen DR, Hill I, Crowe SE, Brown AR, Procaccini NJ, Wonderly BA, Hartley P, Moreci J, Bennett N, Horvath K, Burk M, Fasano A. Detection of celiac disease in primary care: a multicenter case finding study in North America. Am J Gastroenterol. 2007; 102:1454-60

13. Chang M, Green PH. Genetic testing before serologic screening in relatives of patients with celiac disease as a cost containment method. J Clin Gastroenterol. 2009; $43: 43-50$

14. Collin P, Kaukinen K. Serologic screening for coeliac disease in risk groups: is once in the lifetime enough? Dig Liver Dis. 2008;40:101-3.

15. Crovella S, Brandão L, Guimarães R, Filho JL, Arraes LC, Ventura A, Not T. Speeding up coeliac disease diagnosis in developing countries. Dig Liver Dis. 2007;39:900-2.

16. Dube C, Rostom A, Sy R, Cranney A, Saloojee N, Garrity C, Sampson M, Zhang L, Yazdi F, Mamaladze V, Pan I, Macneil J, Mack D, Patel D, Moher D. The prevalence of celiac disease in average-risk and at-risk Western European populations: a systemic review. Gastroenterology. 2005;128:s57-67.

17. Farré C, Humbert P, Vilar P, Varea V, Aldeguer X, Carnicer J, Carballo M, Gassull MA. Serological markers and HLA-DQ2 haplotype among first-degree relatives of celiac patients. Catalonian Coeliac Disease Study Group. Dig Dis Sci. 1999;44:2344-9.

18. Fasano A, Berti I, Gerarduzzi T, Not T, Colletti RB, Drago S, Elitsur Y, Green PH, Guandalini S, Hill ID, Pietzak M, Ventura A, Thorpe M, Kryszak D, Fornaroli F, Wasserman SS, Murray JA, Horvath K. Prevalence of celiac disease in at-risk and not-at-risk groups in the United States: a large multicenter study. Arch Intern Med. 2003;163:286-92. 
19. Gandolfi L, Pratesi R, Cordoba JC, Tauil PL, Gasparin M, Catassi C. Prevalence of celiac disease among blood donors in Brazil. Am J Gastroenterol. 2000;95:689-92.

20. Goldberg D, Kryszak D, Fasano A, Green PH. Screening for celiac disease in family members: is follow-up testing necessary? Dig Dis Sci. 2007;52:1082-6.

21. Greco L, Romino R, Coto I, Di Cosmo N, Percopo S, Maglio M, Paparo F, Gasperi V, Limongelli MG, Cotichini R, D’Agate C, Tinto N, Sacchetti L, Tosi R, Stazi MA. The first large population based twin study of coeliac disease. Gut 2002; 50:624-8.

22. Hadithi M, von Blomberg BM, Crusius JB, Bloemena E, Kostense PJ, Meijer JW, Mulder CJ, Stehouwer CD, Peña AS. Accuracy of serologic tests and HLA-DQ typing for diagnosing celiac disease. Ann Intern Med. 2007;147:294-302.

23. Hill ID, Dirks MH, Liptak GS, Colletti RB, Fasano A, Guandalini S, Hoffenberg EJ, Horvath K, Murray JA, Pivor M, Seidman EG; North American Society for Pediatric Gastroenterology, Hepatology and Nutrition. Guideline for the diagnosis and treatment of celiac disease in children: recommendations of the North American Society for Pediatric Gastroenterology, Hepatology and Nutrition. J Pediatr Gastroenterol Nutr. 2005;40:1-19.

24. Högberg L, Fälth-Magnusson K, Grodzinsky E, Stenhammar L. Familial prevalence of coeliac disease: a twenty-year follow-up study. Scand J Gastroenterol. 2003;38:61-5.

25. Karell K, Louka AS, Moodie SJ, Ascher H, Clot F, Greco L, Ciclitira PJ, Sollid LM, Partanen J. HLA types in celiac disease patients not carrying the DQA $1 * 05-$ DQB1*02 (DQ2) heterodimer: results from the European Genetics Cluster on Celiac disease. Hum Immunol. 2003;64:469-77.

26. Karinen H, Kärkkäinen P, Pihlajamäki J, Janatuinen E, Heikkinen M, Julkunen R, Kosma VM, Naukkarinen A, Laakso M. HLA genotyping is useful in the evaluation of the risk for coeliac disease in the 1st-degree relatives of patients with coeliac disease. Scand J Gastroenterol. 2006;41:1299-304.

27. Koskinen L, Romanos J, Kaukinen K, Mustalahti K, Korponay-Szabo I, Barisani D, Bardella MT, Ziberna F, Vatta S, Széles G, Pocsai Z, Karell K, Haimila K, Adány R, Not T, Ventura A, Mäki M, Partanen J, Wijmenga C, Saavalainen P. Cost-effective HLA typing with tagging SNPs predicts celiac disease risk haplotypes in the Finnish, Hungarian, and Italian populations. Immunogenetics. 2009;61:247-56.

28. Kotze LM, Utiyama SR, Nisihara RM, Zeni MP, de Sena MG, Amarante HMS Antiendomysium antibodies in Brazilian patients with celiac disease and their first degree relatives. Arq Gastroenterol. 2001;38:94-103.

29. Marsh MN. Gluten, major histocompatibility complex, and the small intestine A molecular and immunobiologic approach to the spectrum of gluten sensitivity ("celiac sprue"). Gastroenterology. 1992;102:330-54.

30. Megiorni F, Mora B, Bonamico M, Barbato M, Nenna R, Maiella G, Lulli P, Mazzilli MC. HLA-DQ and risk gradient for celiac disease. Hum Immunol. 2009; 70:55-9.

31. Melo SB, Fernandes MI, Peres LC, Troncon LE, Galvão LC. Prevalence and demographic characteristics of celiac disease among blood donors in Ribeirão Preto, State of São Paulo, Brazil. Dig Dis Sci. 2006;51:1020-5.

32. Monsuur AJ, de Bakker PI, Zhernakova A, Pinto D, Verduijn W, Romanos J, Auricchio R, Lopez A, van Heel DA, Crusius JB, Wijmenga C. Effective detection of human leukocyte antigen risk alleles in celiac disease using tag single nucleotide polymorphisms. PLoS One. 2008;3:e2270.

33. Niveloni S, Pedreira S, Sugai E, Vasquez H, Smecuol E, Fiorini A, Cabanne A, Dezi R, Valero J, Kogan Z, Maurino E, Bai JC. The natural history of gluten sensitivity: report of two new celiac disease patients resulting from a long-term follow-up of non-atrophic, first- degree relatives. Am J Gastroenterol 2000;95:463-8.
34. Oliveira RP, Sdepanian VL, Barreto JA, Cortez AJ, Carvalho FO, Bordin JO, de Camargo Soares MA, da Silva Patrício FR, Kawakami E, de Morais MB, FagundesNeto U. High prevalence of celiac disease in Brazilian blood donor volunteers based on screening by IgA antitissue transglutaminase. Eur J Gastroenterol Hepatol. 2007;19:43-9.

35. Pereira MA, Ortiz-Agostinho CL, Nishitokukado I, Sato MN, Damião AO, Alencar ML, Abrantes-Lemos CP, Cançado EL, de Brito T, Ioshii SO, Valarini SB, Sipahi AM. Prevalence of celiac disease in an urban area of Brazil with predominantly European ancestry. World J Gastroenterol. 2006;12:6546-50.

36. Pittschieler K, Gentili L, Niederhofer H. Onset of coeliac disease: a prospective longitudinal study. Acta Paediatr. 2003;92:1149-52.

37. Polvi A, Arranz E, Fernadez-Arquero M, Collin P, Mäki M, Sanz A, Calvo C, Maluenda C, Westman P, de la Concha EG, Partanen J. HLA-DQ2-negative celiac disease in Finland and Spain. Hum Immunol. 1998;59:169-75.

38. Pratesi R, Gandolfi L, Garcia SG, Modelli IC, Lopes de Almeida P, Bocca AL, Catassi C. Prevalence of coeliac disease: unexplained age-related variation in the same population. Scand J Gastroenterol. 2003;38:747-50.

39. Revised criteria for diagnosis of coeliac disease. Report of Working Group of European Society of Paediatric Gastroenterology and Nutrition. Arch Dis Child. 1990;65:909-11.

40. Rubio-Tapia A, Van Dyke CT, Lahr BD, Zinsmeister AR, El-Youssef M, Moore SB, Bowman M, Burgart LJ, Melton LJ 3rd, Murray JA. Predictors of family risk for celiac disease: a population-based study. Clin Gastroenterol Hepatol 2008;6:983-7.

41. Sacchetti L, Sarrantonio C, Pastore L, Carlino V, Calcagno G, Ferrajolo A, Salvatore F. Rapid identification of HLA DQA $1 * 0501, \mathrm{DQB} 1 * 0201$, and DRB $1 * 04$ alleles in celiac disease by PCR-based methodology. Clin Chem. 1997:43:2204-6.

42. Silva EM, Fernandes MI, Galvão LC, Sawamura R, Donadi EA. Human leucocyte antigen class II alleles in White Brazilian patients with celiac disease. J Pediatr Gastroenterol Nutr. 2000;31:391-4.

43. Sollid LM, Thorsby E. HLA susceptibility genes in celiac disease: genetic mapping and role in pathogenesis. Gastroenterology. 1993;105:910-22

44. Trevisol C, Brandt KG, Silva GA, Crovella S, Ventura. A high prevalence of unrecognized celiac disease in an unselected hospital population in North-Eastern Brazil (Recife-Pernambuco). J Pediatr Gastroenterol Nutr. 2004:39:214-5.

45. Unsworth DJ. ACP Broadsheet No 149: September 1996. Serological diagnosis of gluten sensitive enteropathy. J Clin Pathol. 1996;49:704-11.

46. Utiyama SRR, Nass FR, Kotze LM, Nisihara RM, Ambrosio AR, MessiasReason IT. Serological screening of relatives of celiac disease patients: antiendomysium antibodies, anti-tissue transglutaminase or both? Arq Gastroenterol. 2007;44:156-61.

47. Volta U, Molinaro N, Fusconi M, Cassani F, Bianchi FB. IgA antiendomysial antibody test. A test. A step forward in celiac disease screening. Dig Dis Sci 1991;36:752-6.

48. Wolters VM, Wijmenga C. Genetic background of celiac disease and its clinical implications. Am J Gastroenterol. 2008:103:190-95. 